University of South Florida

DIGITAL COMMONS

Digital Commons @ University of

@ UNIVERSITY OF SOUTH FLORIDA

South Florida

$1-1-2013$

\title{
2013 Work Plan USF Tampa
}

USF

Follow this and additional works at: https://digitalcommons.usf.edu/usf_accountability_reports

\section{Scholar Commons Citation}

USF, "2013 Work Plan USF Tampa" (2013). USF Accountability Reports. 40.

https://digitalcommons.usf.edu/usf_accountability_reports/40

This Article is brought to you for free and open access by the USF Archives at Digital Commons @ University of South Florida. It has been accepted for inclusion in USF Accountability Reports by an authorized administrator of Digital Commons @ University of South Florida. For more information, please contact digitalcommons@usf.edu. 


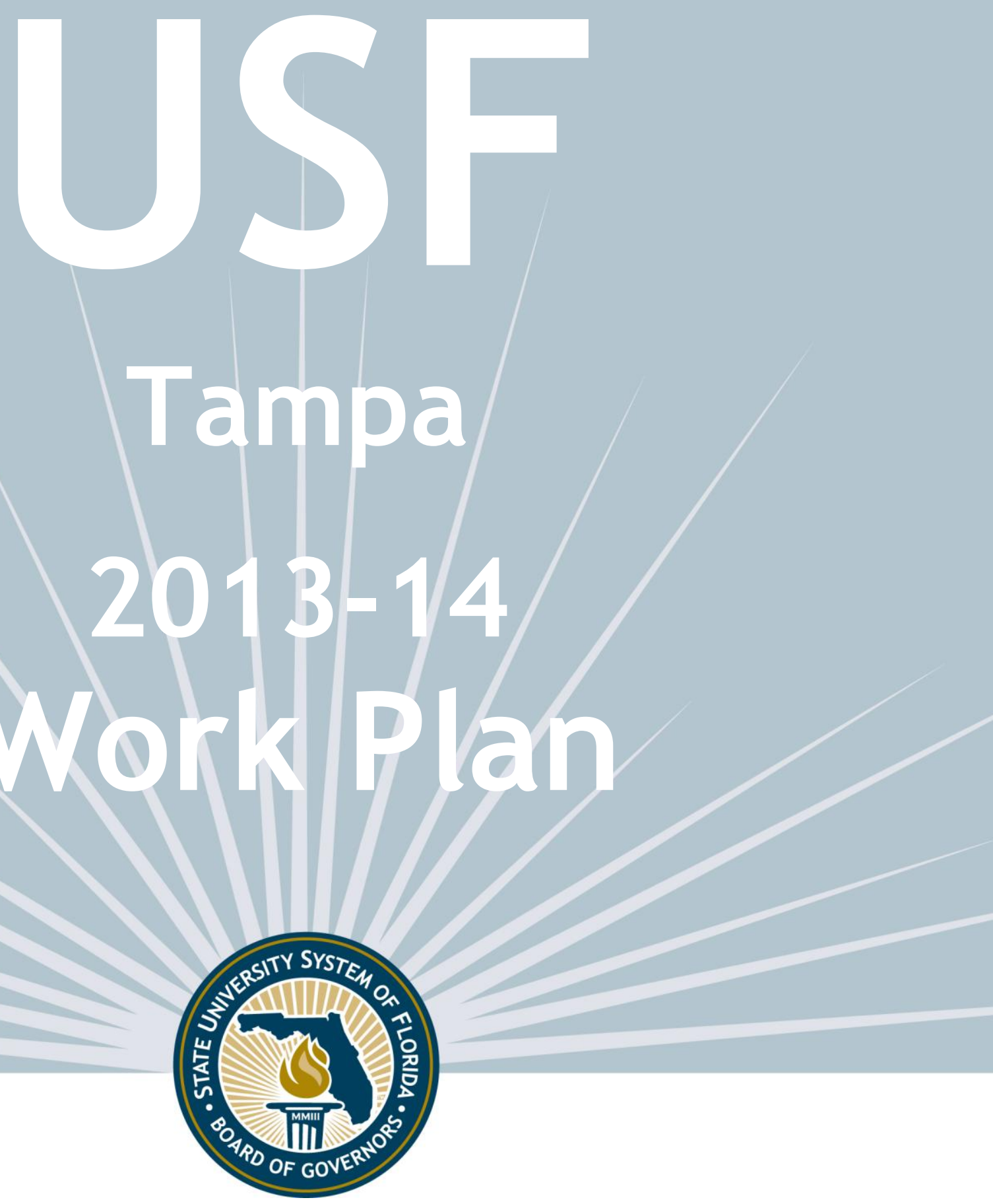

University of South Florida

Work Plan Presentation for 2013-14 Board of Governors Review

STATE UNIVERSITY SYSTEM of FLORIDA Board of Governors 


\section{INTRODUCTION}

The State University System of Florida has developed three tools that aid in guiding the System's future.

1) The Board of Governors' new Strategic Plan 2012-2025 is driven by goals and associated metrics that stake out where the System is headed;

2) The Board's Annual Accountability Report provides yearly tracking for how the System is progressing toward its goals;

3) Institutional Work Plans connect the two and create an opportunity for greater dialogue relative to how each institution contributes to the System's overall vision.

These three documents assist the Board with strategic planning and with setting short-, mid-and long-term goals. They also enhance the System's commitment to accountability and driving improvements in three primary areas of focus: 1) academic quality, 2) operational efficiency, and 3) return on investment.

The Board will use these documents to help advocate for all System institutions and foster even greater coordination with the institutions and their Boards of Trustees.

Once a Work Plan is approved by each institution's respective Boards of Trustees, the Board of Governors will review and consider the plan for potential acceptance of 2013-14 components. Longer-term components will inform future agendas of the Board's Strategic Planning Committee. The Board's acceptance of a work plan does not constitute approval of any particular component, nor does it supersede any necessary approval processes that may be required for each component. 


\section{TABLE OF CONTENTS}

1. STRATEGY
a. Mission Statement
b. Vision Statement
c. Statement of Strategy
d. Strengths and Opportunities
e. Key Initiatives \& Investments

\section{KEY PERFORMANCE INDICATORS}
a. Goals Common to All Universities
b. Goals Specific to Research Universities
c. Institution Specific Goals

3. OPERATIONS
a. Fiscal Information (includes Tuition Differential Fee Request)
b. Enrollment Planning
c. Academic Program Coordination

\section{DEFINITIONS}




\section{MISSION STATEMENT (What is your purpose?)}

The University of South Florida's mission is to deliver competitive undergraduate, graduate, and professional programs, to generate knowledge, foster intellectual development, and ensure student success in a global environment.

\section{VISION STATEMENT (What do you aspire to?)}

The University of South Florida is a global research university dedicated to student success and positioned for membership in the Association of American Universities (AAU).

As Florida's leading metropolitan research university, USF is dedicated to:

- Student access, learning, and success through a vibrant, interdisciplinary, and learner-centered research environment incorporating a global curriculum.

- Research and scientific discovery to strengthen the economy, promote civic culture and the arts, and design and build sustainable communities through the generation, dissemination, and translation of new knowledge across all academic and health-related disciplines.

- Partnerships to build significant locally- and globally-integrated university-community collaborations through sound scholarly and artistic activities and technological innovation.

- A sustainable economic base to support USF's continued academic advancement.

\section{STATEMENT OF STRATEGY (How will you get there?)}

\section{Given your mission, vision, strengths and available resources, provide a brief description of your} market and your strategy for addressing and leading it.

USF is a RU/VH institution attracting students and faculty of the highest caliber. In moving forward towards AAU eligibility, USF measures its progress by setting clear annual targets for a series of metrics and compares itself to peer and aspirational peer institutions. USF uses national benchmarks to monitor: Broad measures of academic institutions through the Integrated Postsecondary Education Data System (IPEDS); Its position in the top tier of American research universities through the Carnegie Foundation for the Advancement of Teaching, along with its designation as a Community Engaged University; Performance indices through the Association of American Universities' (AAU); Ranking of research universities through the National Science Foundation (NSF); Ranking of the scope and quality of graduate programs through the National Research Council (NRC); Ranking by the annual report of the Top American Research Universities (TARU); Annual ranking of National Universities US News and World Report's (USNWR); Technology transfers, start-ups and patents through the Association of University Technology Managers (AUTM); Endowment standings through the National Association of Colleges and University Business Officers (NACUBO); Statistics on international education and study abroad through the Institute of International Education/Open Doors (IIE); Moody's credit rating; and Annual giving through Voluntary Support of Education (CAE/VSE).

These data are available in several web sites which show trends and comparisons for many metrics over the last ten years.

http://www.ods.usf.edu/Plans/Strategic/docs/USF-Planning-Metrics-Matrix-2013.pdf http://www.ods.usf.edu/Plans/PPA/dashboard.htm http://www.ods.usf.edu/Plans/Strategic/docs/USF-Strategic-Plan-2013-2018.pdf 


\section{STRENGTHS AND OPPORTUNITIES (within 3 years)}

What are your core capabilities, opportunities and challenges for improvement?

USF core capabilities include: High impact scholarship, research and creative activities; Excellence in teaching and learning; Success and achievement of its students, faculty, staff and alumni; Diversity; Shared governance; Collegiality, academic freedom, and professional responsibility; Entrepreneurial spirit, partnerships and innovation; Transparent accountability; Global research, community engagement and public service. The challenge will be to maintain institutional quality, increase educational and research productivity, and enhance revenue under reduced state resources.

\section{KEY INITIATIVES \& INVESTMENTS (within 3 years)}

Describe your top three key initiatives for the next three years that will drive improvement in Academic Quality, Operational Efficiency, and Return on Investment.

1 Well-educated global citizens through continuing commitment to student success: (a) Provide highest quality, comprehensive educational programs and student research opportunities to foster critical thinking and intellectual inquiry; (b) Develop diverse, dynamic global citizens and leaders to strengthen communities, and improve quality of life; (c) Enhance student opportunities through transformational learning that is intellectually, scientifically and technologically sound, produces relevant, applied skills and engaged outcomes including a renewed commitment to STEM and health fields; (d) Educate competitive, highly-skilled students for the global workforce who make meaningful contributions to society; and (e) Deliver a globalized curriculum utilizing emerging technologies to increase accessibility and cultural understanding. To reach this goal, USF will: recruit high quality students; promote diversity; infuse global content into curricula; increase study abroad and funding/scholarships; attract global students; partner with international organizations; increase student research awards; add graduate programs especially STEM and health-related disciplines; and grow experiential learning.

\section{High-impact research and innovation to change lives, improve health, and foster sustainable} development and positive societal change: (a) Engage in high-impact research, scholarship, and creative activities that generate new knowledge; (b) Increase global research opportunities and partnerships within the university; (c) Develop strategic interdisciplinary research initiatives that solve critical problems; and (d) Promote community-engaged scholarship and creative activities to benefit society. To reach this goal, USF will: Recruit and retain high quality faculty; build a sustainable research infrastructure; enhance research and grant opportunities; provide training programs to increase external funding; employ emerging technologies to promote research and engagement; increase corporate partnerships; stimulate health and technology innovation; strengthen collaborative partnerships with health, educational, allied science, and engineering entities.

3 A highly effective, major economic engine, creating new partnerships to build a strong and sustainable future for Florida in the global economy: (a) Pursue entrepreneurial endeavors that augment revenue and maximize institutional effectiveness; (b) Establish mutually beneficial partnerships that enhance student access to academic programs, research, and employment opportunities; (c) Provide university stewardship that represents the cornerstone of economic and cultural significance for Florida, the nation, and beyond; (d) Promote a stimulating campus life through diverse academic, economic, cultural, and athletic opportunities; and (e) Align budget and fiscal resources with academic priorities. To reach this goal, USF will: Generate new efficient and effective budget practices; increase understanding and transparency of fiscal affairs; enhance institutional infrastructure by securing mutually beneficial partnerships; market the USF brand via strategic dissemination of information; increase revenue generating patents; establish USF as a community fostering partnerships, employment, K-12 schools, residential opportunities and alumni engagement. 


\section{KEY PERFORMANCE INDICATORS}

The Board of Governors has selected the following Key Performance Indicators from its 2012-2025 System Strategic Plan and from accountability metrics identified by the Florida Legislature. The Key Performance Indicators emphasize three primary areas of focus: Academic Quality, Operational Efficiency, and Return on Investment. The indicators address common goals across all universities while also providing flexibility to address institution-specific goals from a list of metrics in the 2012-2025 System Strategic Plan.

The Goals Specific to Research Universities apply only to those universities classified by the Carnegie Foundation for the Advancement of Teaching as being a 'Research University' 1 , which includes Florida A\&M University (by university request), Florida Atlantic University, Florida International University, Florida State University, University of Central Florida, University of Florida, and the University of South Florida.

1 The Carnegie Foundation for the Advancement of Teaching has developed a well-respected system of categorizing postsecondary institutions that includes consideration of each doctorate-granting university's research activities - for more information see link. 


\section{KEY PERFORMANCE INDICATORS}

\section{Goals Common to All Universities}

\begin{tabular}{|c|c|c|c|c|}
\hline $\begin{array}{l}5 \text { YEAR } \\
\text { TREND } \\
(2006-07 \text { to }\end{array}$ & & & 2013-14 & $\begin{array}{l}3 \text { YEAR } \\
\text { GOALS }\end{array}$ \\
\hline & ACTUAL & ESTIMATES & GOALS & $(2015-16)$ \\
\hline
\end{tabular}

\section{Academic Quality}

National Ranking for University and Programs

USF will (a)Educate competitive, highly-skilled students ready to enter the workforce (including investment in STEM and ranked programs); (b)Engage in high impact research and innovation to improve health and foster positive societal change; and (c)Establish partnerships to enhance student access to academic programs and research to build a strong, sustainable future for Florida in a global economy.

Avg. SAT Score (for 3 subtests)

Avg. High School GPA

Professional/Licensure Exam

First-time Pass Rates ${ }^{2}$

Exams Above National/State Benchmark

Exams Below National/State Benchmark

Percent of Undergraduate Seniors

Participating in a Research Course SUBTOTAL OF IMPROVING METRICS

\section{Operational Efficiency}

Freshman Retention Rate

FTIC Graduation Rates

In 4 years (or less)

In 6 years (or less)

AA Transfer Graduation Rates

In 2 years (or less)

In 4 years (or less)

Percent of Bachelor's Degrees

Without Excess Hours

Average Time to Degree (for FTIC) SUBTOTAL OF IMPROVING METRICS

\section{Return on Investment}

Bachelor's Degrees Awarded

Percent of Bachelor's Degrees in STEM

Graduate Degrees Awarded

Percent of Graduate Degrees in STEM

Percent of Baccalaureate Graduates

Employed in Florida

Percent of Baccalaureate Graduates

Continuing their Education in Florida

Annual Gifts Received (\$M) *

Endowment (\$M) *

\section{SUBTOTAL OF IMPROVING METRICS}

TOTAL OF IMPROVING METRICS

\begin{tabular}{ll}
$4 \% \Delta^{1}$ & 1,77 \\
\hline $9 \% \Delta$ & 3.91 \\
& \\
n/a & \\
n/a & \\
n/a &
\end{tabular}

1,777

3.91

$\begin{array}{ll}4 & 5 \\ 1 & 0\end{array}$

1,785

3.93

1,786

3.94

1,790

A system-wide definition will be determined during the Summer of 2013.

$\begin{array}{llll}2 / 2 & 3 / 3 & 2 / 3 & 3 / 3\end{array}$

$6 \% \Delta$

$87 \%$

$88 \%$

$89 \%$

$90 \%$

$15 \% \Delta$

$35 \%$

$52 \%$

$38 \%$

$56 \%$

$43 \%$

$57 \%$

$48 \%$

$8 \% \Delta$

$3 \% \Delta$

$5 \% \Delta$

$28 \%$

$65 \%$

$29 \%$

$65.5 \%$

$30 \%$

$66 \%$

$54 \%$

$56 \%$

$4.5 \mathrm{yrs}$

$5.0 \mathrm{yrs}$

$7 / 7$

$4.5 \mathrm{yrs}$

$6 / 7$

$63 \%$

$2 \% \Delta$

$7 / 7$

$6 / 7$

$33 \%$

$67 \%$

$61 \%$

$6 / 6$

7,830

7,880

$24 \%$

2,991

2,966

$26 \%$

$69.3 \%$

$69.6 \%$

$18.5 \%$

$19 \%$

$\$ 45.0 \mathrm{M}$

$\$ 47.0 \mathrm{M}$

$\$ 51.0 \mathrm{M}$

$-23 \% \Delta$

$\$ 43.6 \mathrm{M}$

$\$ 360.0 \mathrm{M}$

$\$ 390.0 \mathrm{M}$

$6 / 8$

$7 / 8$

$16 / 18$

$15 / 18$

$8 / 8$

$11 / 14$

$18 / 18$

Notes: (1) SAT trends are based on 4 years, (2) Professional licensure pass rates are based on the 2011-12 Annual Accountability Report with data that spans multiple time periods, (3) Percent of graduates employed and continuing their education is based on 2010-11 data from FETPIP.

*USF System level metric reported only 


\section{KEY PERFORMANCE INDICATORS}

Goals Specific to Research Universities

\begin{tabular}{|c|c|c|c|c|c|}
\hline & $\begin{array}{l}5 \text { YEAR } \\
\text { TREND } \\
(2006-07 \text { to } \\
2011-12) \\
\end{array}$ & $\begin{array}{r}2011-12 \\
\text { ACTUAL }\end{array}$ & $\begin{array}{c}2012-13 \\
\text { ESTIMATES }\end{array}$ & $\begin{array}{l}2013-14 \\
\text { GOALS }\end{array}$ & $\begin{array}{l}3 \text { YEAR } \\
\text { GOALS } \\
(2015-16)\end{array}$ \\
\hline \multicolumn{6}{|l|}{ Academic Quality } \\
\hline Faculty Awards & $-200 \% \Delta$ & 8 & 10 & 12 & 14 \\
\hline National Academy Members & $50 \% \Delta$ & 3 & 3 & 4 & 5 \\
\hline Number of Post-Doctoral Appointees & $64 \% \Delta$ & 300 & 305 & 310 & 320 \\
\hline $\begin{array}{l}\text { Number of Science \& Engineering } \\
\text { Disciplines Nationally Ranked in Top } 100 \\
\text { for Research Expenditures* }\end{array}$ & $\mathrm{n} / \mathrm{a}$ & $\begin{array}{c}5 \\
\text { of } 8\end{array}$ & $\begin{array}{c}5 \\
\text { of } 8\end{array}$ & $\begin{array}{c}5 \\
\text { of } 8\end{array}$ & $\begin{array}{c}6 \\
\text { of } 8\end{array}$ \\
\hline SUBTOTAL OF IMPROVING METRICS & $2 / 3$ & & $2 / 4$ & $3 / 4$ & $4 / 4$ \\
\hline
\end{tabular}

To Be Determined

\section{Return on Investment}

Total Research Expenditures (\$M)

(includes non-Science \& Engineering disciplines)

Science \& Engineering Research

Expenditures (\$M)

Science \& Engineering R\&D Expenditures in Non-Medical/Health Sciences (\$M)

Percent of Research Expenditures funded from External Sources

Patents Issued

Licenses/Options Executed

Licensing Income Received (\$M)

Number of Start-up Companies

National Rank is Higher than Predicted by the Financial Resources Ranking (based on U.S. News \& World Report)

Research Doctoral Degrees Awarded

Professional Doctoral Degrees Awarded SUBTOTAL OF IMPROVING METRICS TOTAL OF IMPROVING METRICS
The Board of Governors will work with Universities to develop metrics associated with Operational Efficiencies.

\begin{tabular}{cccccc}
\hline SUBTOTAL OF IMPROVING METRICS & $20 \% \Delta$ & 146 & 147 & 158 & 175 \\
\hline TOTAL OF IMPROVING METRICS & $\mathbf{5 / 6}$ & & $\mathbf{8 / 1 0}$ & $\mathbf{7 / 1 0}$ & $\mathbf{1 0 / 1 0}$ \\
\hline
\end{tabular}

Note: An asterisk (*) indicates that $2010-11$ is the latest data available for these metrics.

${ }^{* *}$ Potential effects of sequestration.

${ }^{* \star *}$ Reduction in new start-ups based on faculty career expectations; however, projections remain in line with AAU metrics. 


\section{KEY PERFORMANCE INDICATORS}

\section{Institution Specific Goals}

Each university will select three metric goals from the following list of metrics included in the 2012-2025 System Strategic Plan:

\begin{tabular}{|c|c|}
\hline Freshman in Top $10 \%$ of Graduating High School Class & Bachelor's Degrees in Areas of Strategic Emphasis \\
\hline Percentage of Eligible Programs with Specialized Accreditation & Graduate Degrees in Areas of Strategic Emphasis \\
\hline Bachelor's Degrees Awarded to Minorities & Number of Faculty Designated a Highly Cited Scholar \\
\hline Number of Adult (age 25+) Undergraduates Enrolled & $\begin{array}{l}\text { Seek and/or Maintain Carnegie's Community } \\
\text { Engagement Classification (narrative goal) }\end{array}$ \\
\hline \multirow[t]{2}{*}{$\begin{array}{l}\text { Percent of Course Sections Offered via Distance and Blended } \\
\text { Learning }\end{array}$} & $\begin{array}{l}\text { Percentage of Students Participating in Identified } \\
\text { Community and Business Engagement Activities }\end{array}$ \\
\hline & $\begin{array}{l}\text { Enrollment in Professional Training and Continuing } \\
\text { Education Courses }\end{array}$ \\
\hline
\end{tabular}

\begin{tabular}{|c|c|c|c|c|c|}
\hline & $\begin{array}{c}5 \text { YEAR } \\
\text { TREND } \\
(2006-07 \text { to } \\
2011-12) \\
\end{array}$ & $\begin{array}{r}2011-12 \\
\text { ACTUAL } \\
\end{array}$ & $\begin{array}{c}2012-13 \\
\text { ESTIMATES }\end{array}$ & $\begin{array}{l}2013-14 \\
\text { GOALS }\end{array}$ & $\begin{array}{c}3 \text { YEAR GOALS } \\
(2015-16)\end{array}$ \\
\hline $\begin{array}{l}\text { Graduate Degrees in Areas of Strategic } \\
\text { Emphasis }\end{array}$ & $53 \% \Delta$ & 1,616 & 1,637 & 1,657 & 1,757 \\
\hline $\begin{array}{l}\text { Freshman in Top } 10 \% \text { of Graduating High } \\
\text { School Class }\end{array}$ & $7 \% \Delta$ & $32 \%$ & $32 \%$ & $34 \%$ & $40 \%$ \\
\hline $\begin{array}{l}\text { Percent of Course Sections Offered via Distance } \\
\text { and Blended Learning }\end{array}$ & $1 \% \Delta$ & $9.4 \%$ & $10.3 \%$ & $11 \%$ & $12 \%$ \\
\hline
\end{tabular}

To further distinguish the university's distinctive mission, the university may choose to provide two additional narrative and metric goals that are based on the university's own strategic plan.

Goal 1. As an RU/VH institution, with a strategic goal of engaging in high impact research, USF will continue to build a sustainable research infrastructure, including total research expenditures as defined by the National Science Foundation.

Total Research Expenditures

n/a

$\$ 443.2 \mathrm{M} \quad \$ 445 \mathrm{M} \quad \$ 409 \mathrm{M}^{* *}$

$\$ 433 \mathrm{M}$

Goal 2. As an RUNH institution, with a strategic goal of engaging in high impact research, USF will continue to build a sustainable research infrastructure, including federal research expenditures as defined by the National Science Foundation.

Federal Research Expenditures

$n / a$

$\$ 236.0 M \quad \$ 237 M \quad \$ 218 M^{\star *}$

$\$ 231 \mathrm{M}$

${ }^{\star *}$ Potential effects of sequestration. 


\section{OPERATIONS}




\section{FISCAL INFORMATION}

University Revenues (in Millions of Dollars)

\begin{tabular}{|c|c|c|c|c|c|c|}
\hline & $\begin{array}{c}2008-09 \\
\text { Actual }\end{array}$ & $\begin{array}{c}2009-10 \\
\text { Actual }\end{array}$ & $\begin{array}{c}2010-11 \\
\text { Actual }\end{array}$ & $\begin{array}{c}2011-12 \\
\text { Actual }\end{array}$ & $\begin{array}{c}2012-13 \\
\text { Estimated }^{*}\end{array}$ & $\begin{array}{c}2013-14 \\
\text { Appropriations }\end{array}$ \\
\hline \multicolumn{7}{|c|}{ Education \& General - Main Operations ${ }^{* *}$} \\
\hline State Funds & $\$ 248.51$ & $\$ 231.80$ & $\$ 254.56$ & $\$ 217.17$ & $\$ 155.20$ & $\mathrm{n} / \mathrm{a}$ \\
\hline Tuition & $\$ 99.53$ & $\$ 108.00$ & $\$ 122.72$ & $\$ 137.20$ & $\$ 152.00$ & $\mathrm{n} / \mathrm{a}$ \\
\hline TOTAL MAIN OPERATIONS & $\$ 348.04$ & $\$ 339.79$ & $\$ 377.28$ & $\$ 354.37$ & $\$ 307.20$ & n/a \\
\hline \multicolumn{7}{|c|}{ Education \& General - Health-Science Center / Medical Schools } \\
\hline State Funds & $\$ 62.7$ & $\$ 66.1$ & $\$ 67.3$ & $\$ 63.4$ & $\$ 66.2$ & $\mathrm{n} / \mathrm{a}$ \\
\hline Tuition & $\$ 26.4$ & $\$ 30.5$ & $\$ 33.9$ & $\$ 42.8$ & $\$ 52.7$ & $\mathrm{n} / \mathrm{a}$ \\
\hline TOTAL HSC & $\$ 89.1$ & $\$ 96.6$ & $\$ 101.20$ & $\$ 106.20$ & $\$ 118.30$ & $\mathrm{n} / \mathrm{a}$ \\
\hline
\end{tabular}

State Funds

Tuition

N/A

TOTAL IFAS

\begin{tabular}{|c|c|c|c|c|c|}
\hline $\begin{array}{l}\text { EDUCATION \& GENERAL } \\
\text { TOTAL REVENUES }\end{array}$ & $\$ 437.14$ & $\$ 436.39$ & $\$ 478.48$ & $\$ 460.57$ & $\$ 425.50$ \\
\hline
\end{tabular}

*2012-13 estimated data is the 2012-13 operating budget

**Educational \& General - Main Operations for USF Tampa includes the $\$ 10 \mathrm{M}$ allocated for the Lakeland Teach-Out

Note: State funds include General Revenue funds, Lottery funds, Federal Stimulus funds, and Phosphate Research funds (for Polytechnic) appropriated by the Florida Legislature (as reported in the Annual Accountability Report). Actual tuition includes base tuition and tuition differential fee revenues for resident and non-resident undergraduate and graduate students net of waivers (as reported in the Annual Accountability Report).

Actual tuition revenues are not yet available for the 2013-14 year.

\section{OTHER BUDGET ENTITIES -}

\section{Auxiliary Enterprises}

Resources associated with auxiliary units that are self-supporting through fees, payments and charges. Examples include housing, food services, bookstores, parking services, health centers.

$\begin{array}{lllll}\text { Revenues } & \text { Previously reported only at the USF System Level } & \$ 156.1 & \$ 158.4 & \text { n/a }\end{array}$

\section{Contracts \& Grants}

Resources received from federal, state or private sources for the purposes of conducting research and public service activities.
Revenues
Previously reported only at the USF System Level
$\$ 249.7$
$\$ 373.7$
n/a

\section{Local Funds}

Resources associated with student activity (supported by the student activity fee), student financial aid, concessions, intercollegiate athletics, technology fee, green fee, and student life \& services fee.

$\begin{array}{lllll}\text { Revenues } & \text { Previously reported only at the USF System Level } & \$ 440.2 & \$ 437.8 & \text { n/a }\end{array}$

\section{Faculty Practice Plans}

Revenues/receipts are funds generated from faculty practice plan activities.

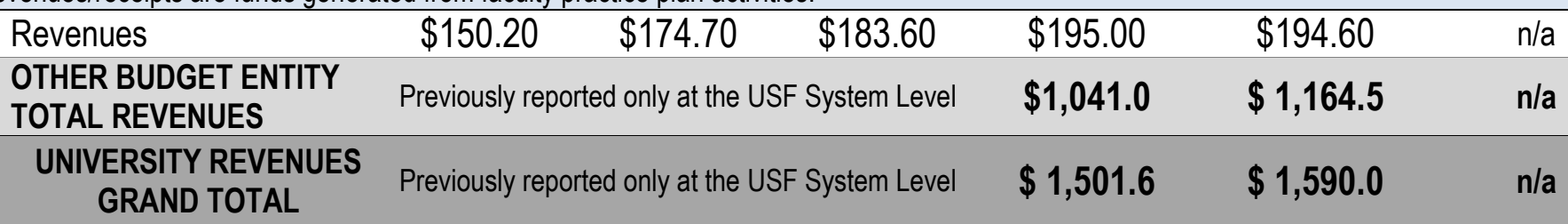




\section{FISCAL INFORMATION (continued)}

Undergraduate Resident Tuition Summary (for 30 credit hours)

\begin{tabular}{lccccc} 
& $\begin{array}{c}\text { FY 2011-12 } \\
\text { ACTUAL }\end{array}$ & $\begin{array}{c}\text { FY 2012-13 } \\
\text { ACTUAL }\end{array}$ & $\begin{array}{c}\text { FY 2013-14 } \\
\text { REQUEST }\end{array}$ & $\begin{array}{c}\text { FY 2014-15 } \\
\text { PLANNED }\end{array}$ & $\begin{array}{c}\text { FY 2015-16 } \\
\text { PLANNED }\end{array}$ \\
\hline Base Tuition & $\$ 3,100$ & $\$ 3,100$ & $\$ 3,152$ & $\$ 3,152$ & $\$ 3,152$ \\
\hline Tuition Differential Fee & $\$ 960$ & $\$ 1,406$ & $\$ 1,406$ & $\$ 1,406$ & $\$ 1,406$ \\
\hline Percent Increase & $15 \%$ & $11 \%$ & $1.2 \%$ & $0 \%$ & $0 \%$ \\
\hline Required Fees $^{1}$ & $\$ 1,746$ & $\$ 1,828$ & $\$ 1,851$ & $\$ 1,851$ & $\$ 1,851$ \\
\hline TOTAL TUITION AND FEES & $\$ 5,806$ & $\$ 6,334$ & $\$ 6,410$ & $\$ 6,410$ & $\$ 6,410$
\end{tabular}

Note 1: For more information regarding required fees see list of per credit hour fees and block fees on page 16.

\section{Student Debt Summary}

\begin{tabular}{lccccc} 
& $\begin{array}{c}2008-09 \\
\text { ACTUAL }\end{array}$ & $\begin{array}{c}2009-10 \\
\text { ACTUAL }\end{array}$ & $\begin{array}{c}2010-11 \\
\text { ACTUAL }\end{array}$ & $\begin{array}{c}2011-12 \\
\text { ACTUAL }\end{array}$ & $\begin{array}{c}2012-13 \\
\text { ESTIMATE }\end{array}$ \\
\hline Percent of Bachelor's Recipients with Debt & $52 \%$ & $52 \%$ & $53 \%$ & $57 \%$ & $57 \%$ \\
Average Amount of Debt & $\$ 19,963$ & $\$ 21,811$ & $\$ 21,784$ & $\$ 22,623$ & $\$ 22,600$ \\
for Bachelor's who have graduated with debt & $7.0 \%$ & $6.8 \%$ & $5.5 \%$ draft & $\mathrm{n} / \mathrm{a}$ & $\mathrm{n} / \mathrm{a}$ \\
\hline Student Loan Cohort Default Rate (2nd Year) & $9.8 \%$ & $\mathrm{n} / \mathrm{a}$ & $\mathrm{n} / \mathrm{a}$ & $\mathrm{n} / \mathrm{a}$ & $\mathrm{n} / \mathrm{a}$
\end{tabular}

Note: Student Loan cohort default data includes undergraduate and graduate students.

*USF System data

Cost of Attendance (for Full-Time Undergraduate Florida Residents in the Fall and Spring of 2012-13)

\begin{tabular}{ccccccc} 
& $\begin{array}{c}\text { TUITION } \\
\& \text { FEES }\end{array}$ & $\begin{array}{c}\text { BOOKS \& } \\
\text { SUPPLIES }\end{array}$ & $\begin{array}{c}\text { ROOM } \\
\text { \& BOARD }\end{array}$ & TRANSPORTATION & $\begin{array}{c}\text { OTHER } \\
\text { EXPENSES }\end{array}$ & TOTAL \\
\hline ON-CAMPUS & $\$ 6,334$ & $\$ 1,000$ & $\$ 8,960$ & $\$ 1,600$ & $\$ 2,500$ & $\$ \mathbf{2 0 , 3 9 4}$ \\
\hline AT HOME & $\$ 6,334$ & $\$ 1,000$ & $\$ 4,480$ & $\$ 1,600$ & $\$ 2,500$ & $\$ 15,914$ \\
\hline
\end{tabular}

Estimated Net Cost by Family Income (for Full-Time Undergraduate Florida Residents in the Fall and Spring of 2012-13)

\begin{tabular}{|c|c|c|c|c|c|c|}
\hline \multirow{2}{*}{$\begin{array}{l}\text { FAMILY } \\
\text { INCOME } \\
\text { GROUPS }\end{array}$} & \multicolumn{2}{|c|}{$\begin{array}{l}\text { FULL-TIME RESIDENT } \\
\text { UNDERGRADUATES }\end{array}$} & \multirow{2}{*}{$\begin{array}{c}\text { AVG. NET } \\
\text { COST OF } \\
\text { ATTENDANCE }\end{array}$} & \multirow{2}{*}{$\begin{array}{c}\text { AVG. NET } \\
\text { TUITION } \\
\& \text { FEES }\end{array}$} & \multirow{2}{*}{$\begin{array}{l}\text { AVERAGE } \\
\text { GIFT AID } \\
\text { AMOUNT }\end{array}$} & \multirow{2}{*}{$\begin{array}{l}\text { AVERAGE } \\
\text { LOAN } \\
\text { AMOUNT }\end{array}$} \\
\hline & HEADCOUNT & PERCENT & & & & \\
\hline Below $\$ 40,000$ & 6,758 & $38 \%$ & $\$ 11,073$ & $-\$ 2,711$ & $\$ 8,629$ & $\$ 4,197$ \\
\hline$\$ 40,000-\$ 59,999$ & 2,242 & $12 \%$ & $\$ 13,150$ & $-\$ 327$ & $\$ 6,322$ & $\$ 3,968$ \\
\hline$\$ 60,000-\$ 79,999$ & 1,813 & $10 \%$ & $\$ 15,192$ & $\$ 1,821$ & $\$ 4,212$ & $\$ 4,275$ \\
\hline$\$ 80,000-\$ 99,999$ & 1,467 & $8 \%$ & $\$ 16,062$ & $\$ 2,736$ & $\$ 3,309$ & $\$ 4,279$ \\
\hline$\$ 100,000$ Above & 4,407 & $25 \%$ & $\$ 16,273$ & $\$ 2,949$ & $\$ 3,121$ & $\$ 2,947$ \\
\hline Missing & 1,200 & $7 \%$ & $\$ 17,515$ & $\$ 5,032$ & $\$ 996$ & $\$ 273$ \\
\hline TOTAL & 17,887 & $100 \%$ & $\$ 13,873$ & $\$ 407$ & $\$ 5,587$ & $\$ 3,612$ \\
\hline
\end{tabular}

Notes: This data only represents Fall and Spring financial aid data and is accurate as of March 31, 2013. Please note that small changes to Spring 2013 awards are possible before the data is finalized. Family Income Groups are based on the Total Family Income (including untaxed income) as reported on student FAFSA records. Full-time Students is a headcount based on at least 24 credit hours during Fall and Spring terms. Average Gift Aid includes all grants and scholarships from Federal, State, University and other private sources administered by the Financial Aid Office. Student waivers are also included in the Gift Aid amount. Gift Aid does not include the parental contribution towards EFC. Net Cost of Attendance is the actual average of the total Costs of Attendance (which will vary by income group due to the diversity of students living on- \& off- campus) minus the average Gift Aid amount. Net Tuition \& Fees is the actual average of the total costs of tuition and fees (which will vary by income group due to the amount of credit hours students are enrolled) minus the average Gift Aid amount (see page 16 for list of fees that are included). Average Loan Amount includes Federal (Perkins, Stafford, Ford Direct, and PLUS loans) and all private loans. The bottom-line Average represents the average of all full-time undergraduate Florida residents. 


\section{FISCAL INFORMATION (continued) \\ TUITION DIFFERENTIAL FEE INCREASE REQUEST FOR FALL 2013}

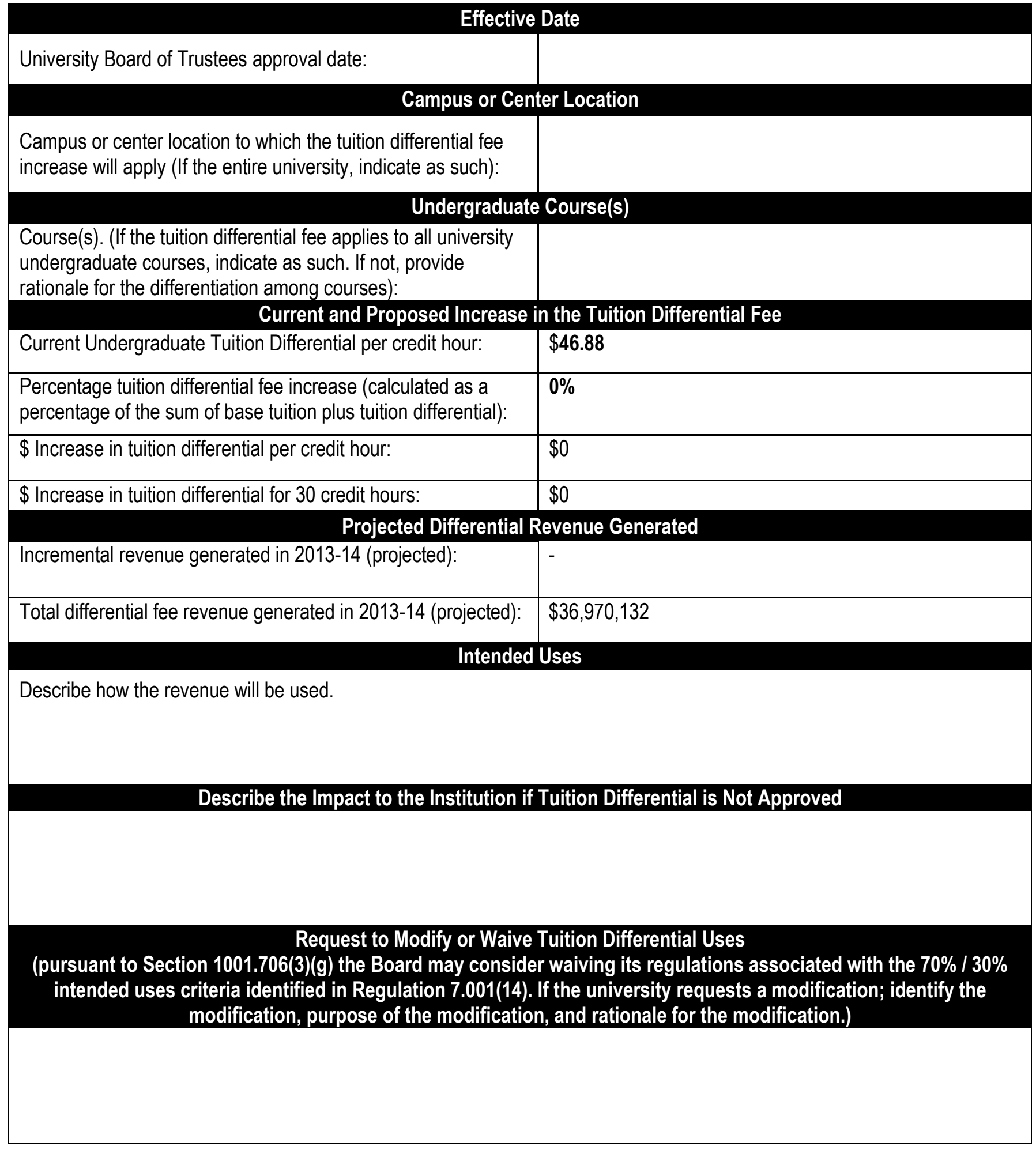




\section{FISCAL INFORMATION (continued) TUITION DIFFERENTIAL SUPPLEMENTAL INFORMATION}

\section{Provide the following information for the 2012-13 academic year.}

2012-2013 - 60\% Initiatives (list the initiatives provided in the 2012-13 tuition differential request)

Expanding the high-skilled workforce and assuring job placement, especially in STEM

Academic advising and veteran's support

Financial counseling and debt reduction

\section{University Update on Each Initiative}

Expanded professional support for job placement through USF's Career Center/Job Hub; initiated Task Force to promote student internships.

Enhanced academic advising through the development of an academic tracking system that will be launched in 2013; created a new position in Undergraduate Studies to provide greater direction to Academic Advising and Tracking; more intense focus on accelerating time-to-degree through development of 4-year plans. Course redesigns, class scheduling; expanded USF's Veterans' Success program. Improved tracking of students and graduates. Launched Bull2Bull financial education program, using peer educators to promote financial literacy and provide students with personal financial management skills through group and one-onone financial education sessions.

\section{Additional Detail, where applicable:}

Total Number of Faculty Hired or Retained (funded by tuition 24

differential):

Total Number of Advisors Hired or Retained (funded by tuition differential):

Total Number of Course Sections Added or Saved (funded by tuition differential):

\section{2-2013 - 40\% Initiatives (list the initiatives provided in} the 2012-13 tuition differential request)

Expand access for students and accelerated path to graduation

Provide financial support for talented students with limited income

More students supported with financial aid scholarships and reduced loan indebtedness

\section{6}

\section{8 courses}

\section{University Update on Each Initiative}

113 senior students were incentivized to graduate in four years with a $\$ 2,500$ grant which will repay $\$ 2,500$ in student loans if the student graduated in spring 2013. Seventy-five students indicated interest and awards will be made once degree verification can be confirmed.

Larger USF need based grant awards were made to students based on their academic potential and USF academic record. The number of students receiving a need based grant increased from 6,246 to 7,033 , or by $13 \%$.

\section{Additional Information (estimates as of April 30, 2013):}

\begin{tabular}{|l|l}
\hline Unduplicated Count of Students Receiving at least one & 7,033
\end{tabular}

Tuition Differential-Funded Award:

\begin{tabular}{|l|l}
\hline Mean (per student receiving an award) of Tuition & $\$ 1,468$
\end{tabular}

Differential-Funded Awards:

\begin{tabular}{|l|l} 
\$ Minimum (per student receiving an award) of Tuition & $\$ 121$
\end{tabular}

Differential-Funded Awards:

\begin{tabular}{|l|l}
\hline Maximum (per student receiving an award) of Tuition & $\$ 4,000$
\end{tabular}

Differential-Funded Awards: 


\section{FISCAL INFORMATION (continued) \\ TUITION DIFFERENTIAL COLLECTIONS, EXPENDITURES, \& AVAILABLE BALANCES - FISCAL YEAR 2012-13 AND 2013-14}

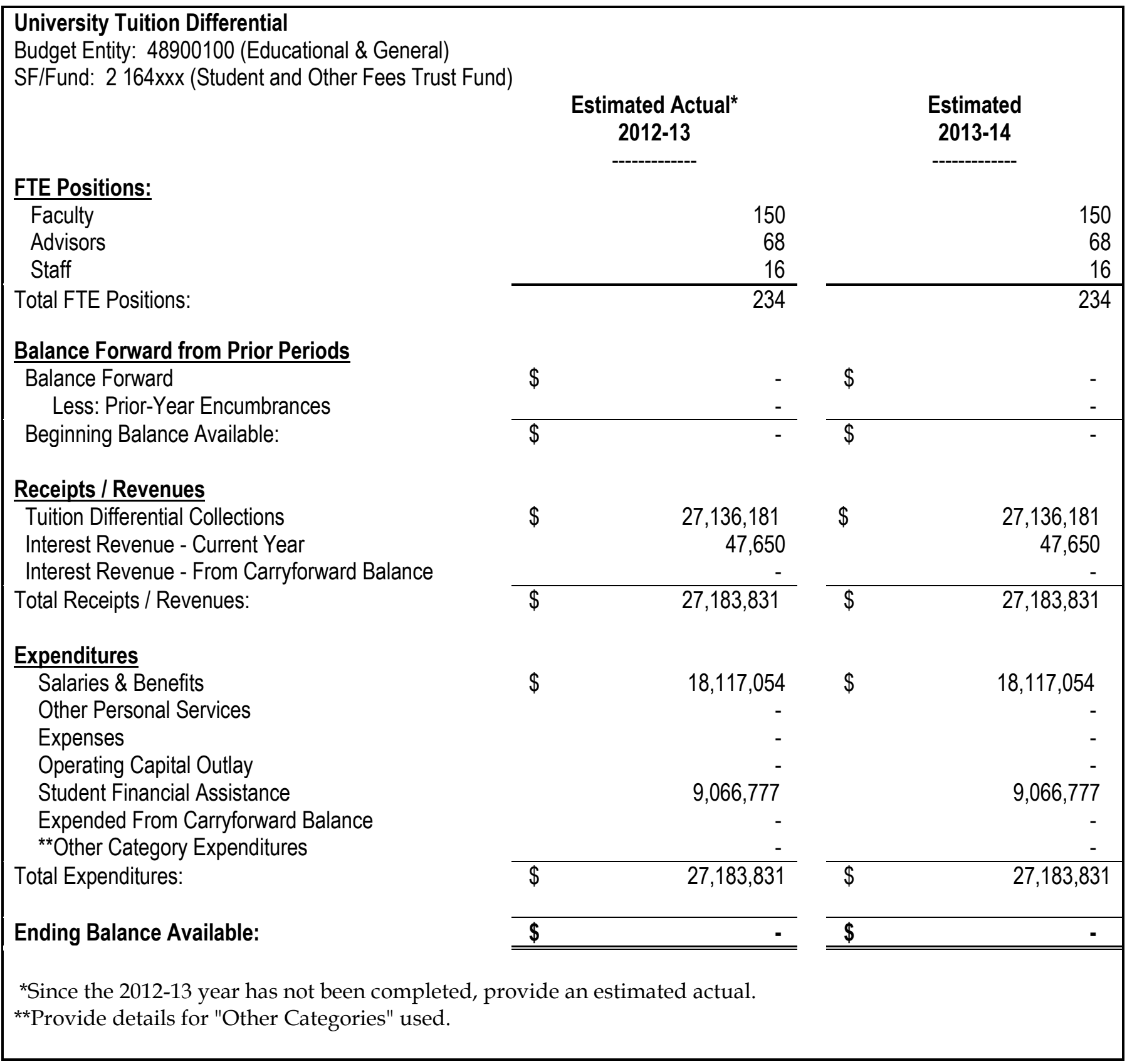

Note: Data are current as of March 31, 2013 


\section{FISCAL INFORMATION (continued) \\ UNIVERSITY TUITION, FEES AND HOUSING PROJECTIONS ENROLLMENT PLANNING}

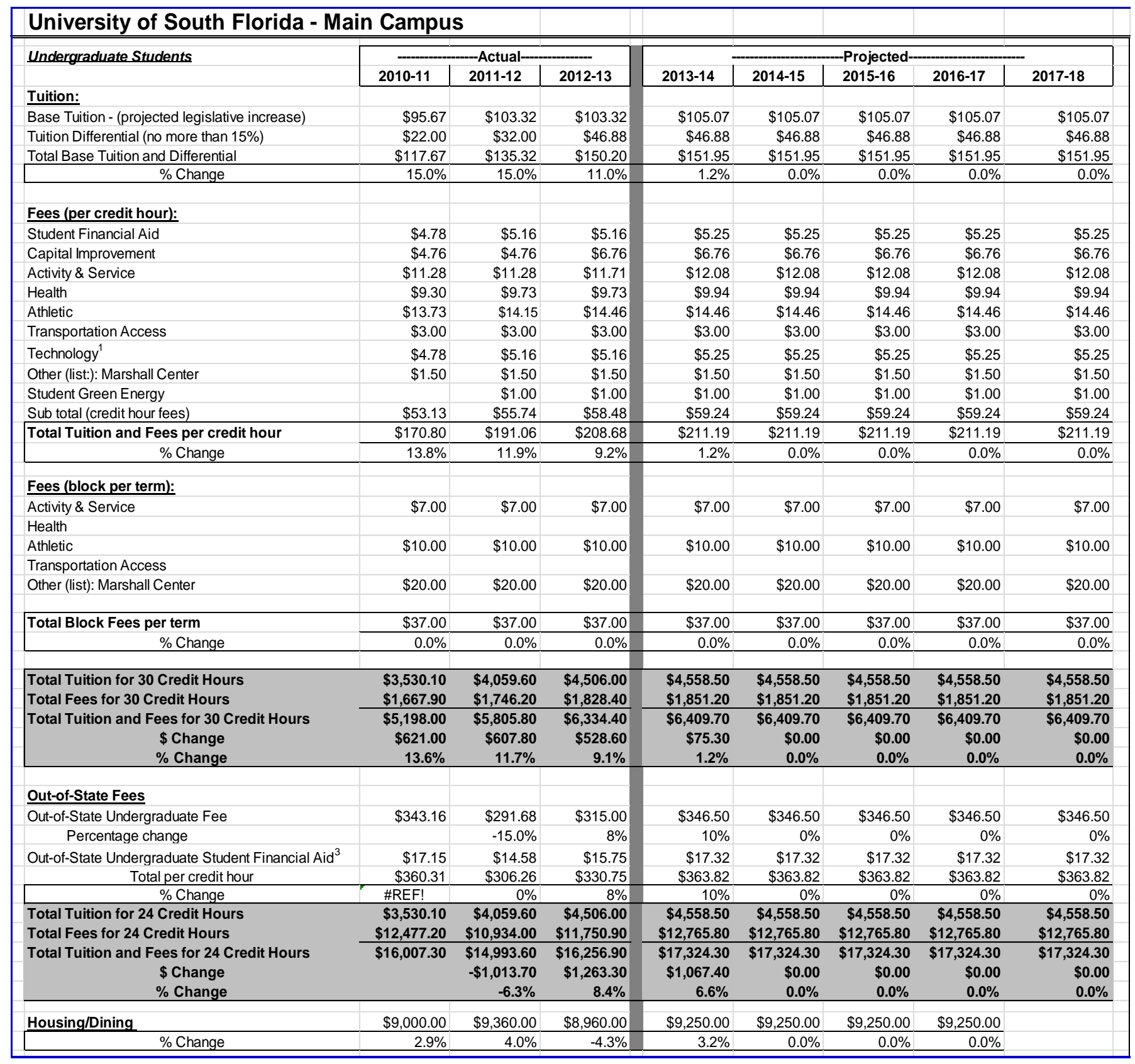


Planned Growth by Student Type (for all E\&G students at all campuses)

\begin{tabular}{|c|c|c|c|c|c|c|c|c|c|}
\hline \multirow{2}{*}{ UNDERGRADUATE } & \multirow{2}{*}{$\begin{array}{l}5 \text { YEAR } \\
\text { TREND } \\
\text { (2006-07 to } \\
\text { 2011-12) } \\
\end{array}$} & \multicolumn{2}{|c|}{$\begin{array}{c}2011-12 \\
\text { ACTUAL } \\
\text { HEADCOUNT }\end{array}$} & \multicolumn{2}{|c|}{$\begin{array}{c}\text { 2013-14 } \\
\text { PLANNED } \\
\text { HEADCOUNT }\end{array}$} & \multicolumn{2}{|c|}{$\begin{array}{c}2014-15 \\
\text { PLANNED } \\
\text { HEADCOUNT }\end{array}$} & \multicolumn{2}{|c|}{$\begin{array}{c}2015-16 \\
\text { PLANNED } \\
\text { HEADCOUNT }\end{array}$} \\
\hline & & & & & & & & & \\
\hline FTIC (Regular Admit) & $-3 \% \Delta$ & 15,535 & $51 \%$ & 15,600 & $52 \%$ & 15,100 & $51 \%$ & 14,700 & $52 \%$ \\
\hline FTIC (Profile Admit) & $-64 \% \Delta$ & 181 & $1 \%$ & 200 & $1 \%$ & 200 & $1 \%$ & 250 & $1 \%$ \\
\hline AA Transfers* & $29 \% \Delta$ & 9,634 & $32 \%$ & 8,725 & $29 \%$ & 8,550 & $29 \%$ & 7,950 & $28 \%$ \\
\hline Other Transfers & $-12 \%$ & 5,015 & $17 \%$ & 5,375 & $18 \%$ & 5,500 & $19 \%$ & 5,400 & $19 \%$ \\
\hline Subtotal & $2 \% \Delta$ & 30,365 & $100 \%$ & 29,900 & $100 \%$ & 29,350 & $100 \%$ & 28,300 & $100 \%$ \\
\hline \multicolumn{10}{|l|}{ GRADUATE STUDENTS } \\
\hline Master's & $15 \% \Delta$ & 5,843 & $66 \%$ & 6,200 & $65 \%$ & 6,350 & $65 \%$ & 6,400 & $62 \%$ \\
\hline Research Doctoral & $20 \% \Delta$ & 2,362 & $27 \%$ & 2,335 & $25 \%$ & 2,358 & $24 \%$ & 2,750 & $27 \%$ \\
\hline Professional Doctoral & $28 \% \Delta$ & 676 & $8 \%$ & 972 & $10 \%$ & 1,080 & $11 \%$ & 1,180 & $11 \%$ \\
\hline Subtotal & $17 \% \Delta$ & 8,881 & $100 \%$ & 9,507 & $100 \%$ & 9,788 & $100 \%$ & 10,330 & $100 \%$ \\
\hline NOT-DEGREE SEEKING & $2 \% \Delta$ & 1,789 & & 1,650 & & 1,800 & & 1,800 & \\
\hline MEDICAL & $\% \Delta$ & 480 & & 480 & & 480 & & 480 & \\
\hline TOTAL & $\% \Delta$ & 41,515 & & 41,537 & & 41,418 & & 40,910 & \\
\hline
\end{tabular}

Note*: AA transfers refer only to transfers from the Florida College System.

Planned Growth by Method of Instruction (for all E\&G students at all campuses)

\begin{tabular}{|c|c|c|c|c|c|c|c|c|c|}
\hline & \multirow{2}{*}{$\begin{array}{c}5 \text { YEAR } \\
\text { TREND } \\
\text { (2006-07 to } \\
2011-12)\end{array}$} & \multicolumn{2}{|c|}{ 2011-12 } & \multicolumn{2}{|c|}{ 2013-14 } & \multicolumn{2}{|c|}{ 2014-15 } & \multicolumn{2}{|c|}{$2015-16$} \\
\hline & & $\begin{array}{c}\text { ACTUAL } \\
\text { FTE }\end{array}$ & $\begin{array}{c}\% \text { of } \\
\text { TOTAL }\end{array}$ & $\begin{array}{l}\text { PLANNED } \\
\text { FTE }\end{array}$ & $\begin{array}{c}\% \text { of } \\
\text { TOTAL }\end{array}$ & $\begin{array}{l}\text { PLANNED } \\
\text { FTE }\end{array}$ & $\begin{array}{c}\% \text { of } \\
\text { TOTAL }\end{array}$ & $\begin{array}{l}\text { PLANNED } \\
\text { FTE }\end{array}$ & $\begin{array}{c}\% \text { of } \\
\text { TOTAL }\end{array}$ \\
\hline \multicolumn{10}{|l|}{ UNDERGRADUATE } \\
\hline DISTANCE $(>80 \%)$ & $19 \% \Delta$ & 4,080 & $19 \%$ & 4,090 & $20 \%$ & 4,100 & $20 \%$ & 4,111 & $20 \%$ \\
\hline HYBRID (50\%-79\%) & $0 \% \Delta^{*}$ & 344 & $2 \%$ & 346 & $2 \%$ & 347 & $2 \%$ & 349 & $2 \%$ \\
\hline TRADITIONAL (<50\%) & $-1 \% \Delta$ & 16,582 & $79 \%$ & 16,340 & $79 \%$ & 16,398 & $79 \%$ & 16,373 & $79 \%$ \\
\hline TOTAL & $4 \% \Delta$ & 21,007 & $100 \%$ & 20,776 & $100 \%$ & 20,846 & $100 \%$ & 20,833 & $100 \%$ \\
\hline \multicolumn{10}{|l|}{ GRADUATE } \\
\hline DISTANCE $(80 \%)$ & $37 \% \Delta$ & 989 & $19 \%$ & 1,088 & $21 \%$ & 1,197 & $21 \%$ & 1,316 & $22 \%$ \\
\hline HYBRID (50\%-79\%) & $0 \% \Delta^{*}$ & 145 & $3 \%$ & 146 & $3 \%$ & 161 & $3 \%$ & 180 & $3 \%$ \\
\hline TRADITIONAL $(<50 \%)$ & $7 \% \Delta$ & 4,090 & $78 \%$ & 4,003 & $76 \%$ & 4,214 & $76 \%$ & 4,505 & $75 \%$ \\
\hline TOTAL & $15 \% \Delta$ & 5,224 & $100 \%$ & 5,237 & $100 \%$ & 5,572 & $100 \%$ & 6,001 & $100 \%$ \\
\hline
\end{tabular}

*Hybrid indicator only used from 2010-11 and on

Note: Full-time Equivalent (FTE) student is a measure of instructional effort (and student activity) that is based on the number of credit hours that students enroll. FTE is based on the Florida definition, which divides undergraduate credit hours by 40 and graduate credit hours by 32. Distance Learning is a course in which at least 80 percent of the direct instruction of the course is delivered using some form of technology when the student and instructor are separated by time or space, or both (per 1009.24(17), F.S.). Hybrid is a course where $50 \%$ to $79 \%$ of the instruction is delivered using some form of technology, when the student and instructor are separated by time or space, or both (per SUDS data element 2052). Traditional (and Technology Enhanced) refers to primarily face to face instruction utilizing some form of technology for delivery of supplemental course materials for no more than $49 \%$ of instruction (per SUDS data element 2052). 


\section{ENROLLMENT PLANNING (continued)}

Statutorily Required Enrollment Plan (Based on State-Fundable Florida FTE)*

${ }^{*}$ Reflects Tampa + HSC +Lakeland

\begin{tabular}{|c|c|c|c|c|c|c|c|c|c|}
\hline & $\begin{array}{l}\text { Funded } \\
\text { 2012-13 }\end{array}$ & $\begin{array}{c}\text { Estimated } \\
\text { Actual } \\
2012-13\end{array}$ & $\begin{array}{l}\text { Funded } \\
\text { 2013-14 }\end{array}$ & $\begin{array}{c}1^{\text {st }} \text { Year } \\
\text { Estimated } \\
2013-14\end{array}$ & $\begin{array}{c}2^{\text {nd }} \text { Year } \\
\text { Planned } \\
2014-15\end{array}$ & $\begin{array}{c}3^{\text {rd }} \text { Year } \\
\text { Planned } \\
2015-16\end{array}$ & $\begin{array}{c}4^{\text {th }} \text { Year } \\
\text { Planned } \\
2016-17\end{array}$ & $\begin{array}{c}5^{\text {th }} \text { Year } \\
\text { Planned } \\
2017-18\end{array}$ & $\begin{array}{c}\text { 5-Year } \\
\text { Projected } \\
\text { Average } \\
\text { Annual } \\
\text { Growth } \\
\text { Rate }\end{array}$ \\
\hline \multicolumn{10}{|c|}{ Florida Resident } \\
\hline LOWER & 8720 & 8031 & 8720 & 7658 & 7757 & 7760 & 7893 & 8023 & $5 \%$ \\
\hline UPPER & 11077 & 11829 & 11077 & 11514 & 11191 & 10885 & 10555 & 10304 & $-11 \%$ \\
\hline GRAD I & 3270 & 3076 & 3270 & 2914 & 2914 & 2979 & 3096 & 3166 & $9 \%$ \\
\hline GRAD II & 855 & 969 & 855 & 918 & 998 & 1067 & 1166 & 1254 & $37 \%$ \\
\hline TOTAL & 23,922 & 23,905 & 23,922 & 23,004 & 22,860 & 22,691 & 22,710 & 22,747 & $-1 \%$ \\
\hline \multicolumn{10}{|c|}{ Non- Resident } \\
\hline LOWER & $\mathrm{n} / \mathrm{a}$ & 537 & $\mathrm{n} / \mathrm{a}$ & 771 & 981 & 1192 & 1212 & 1232 & $60 \%$ \\
\hline UPPER & $\mathrm{n} / \mathrm{a}$ & 488 & $\mathrm{n} / \mathrm{a}$ & 627 & 710 & 789 & 765 & 747 & $19 \%$ \\
\hline GRAD I & $\mathrm{n} / \mathrm{a}$ & 543 & $\mathrm{n} / \mathrm{a}$ & 740 & 880 & 1055 & 1097 & 1122 & $52 \%$ \\
\hline GRAD II & $\mathrm{n} / \mathrm{a}$ & 600 & $\mathrm{n} / \mathrm{a}$ & 664 & 780 & 900 & 984 & 1058 & $59 \%$ \\
\hline TOTAL & 1,302 & 2,168 & 1,302 & 2,802 & 3,351 & 3,936 & 4,058 & 4,159 & $48 \%$ \\
\hline \multicolumn{10}{|l|}{ TOTAL } \\
\hline LOWER & 8,720 & 8,568 & 8,720 & 8,429 & 8,738 & 8,952 & 9105 & 9255 & $10 \%$ \\
\hline UPPER & 11,077 & 12,317 & 11,077 & 12,141 & 11,901 & 11,674 & 11320 & 11051 & $-9 \%$ \\
\hline GRAD I & 3,270 & 3,619 & 3,270 & 3,654 & 3,794 & 4,034 & 4193 & 4288 & $17 \%$ \\
\hline GRAD ॥ & 855 & 1,569 & 855 & 1,582 & 1,778 & 1,967 & 2,150 & 2,312 & $46 \%$ \\
\hline TOTAL & 25,224 & 26,073 & 25,224 & 25,806 & 26,211 & 26,627 & 26,768 & 26,906 & $4 \%$ \\
\hline $\begin{array}{l}\text { TOTAL } \\
\text { (US FTE) }\end{array}$ & 33,632 & 34,764 & 33,632 & 34,408 & 34,948 & 35,503 & 35,691 & 35,875 & $4 \%$ \\
\hline
\end{tabular}

Medical Student Headcounts (FTE does not apply)

\begin{tabular}{|c|c|c|c|c|c|c|c|c|c|}
\hline \multicolumn{10}{|l|}{ Medical Doctorate } \\
\hline FLORIDA RESIDENT & 480 & 448 & 480 & 448 & 448 & 448 & 448 & 448 & $0 \%$ \\
\hline NON-RESIDENT & 0 & 32 & 0 & 32 & 32 & 32 & 32 & 32 & $0 \%$ \\
\hline TOTAL & 480 & 480 & 480 & 480 & 480 & 480 & 480 & 480 & $0 \%$ \\
\hline \multicolumn{10}{|l|}{ Dentistry } \\
\hline FLORIDA RESIDENT & 0 & 0 & 0 & 0 & 0 & 0 & 0 & 0 & $\%$ \\
\hline NON-RESIDENT & 0 & 0 & 0 & 0 & 0 & 0 & 0 & 0 & $\%$ \\
\hline TOTAL & 0 & 0 & 0 & 0 & 0 & 0 & 0 & 0 & $\%$ \\
\hline \multicolumn{10}{|l|}{ Veterinary } \\
\hline FLORIDA RESIDENT & 0 & 0 & 0 & 0 & 0 & 0 & 0 & 0 & $\%$ \\
\hline NON-RESIDENT & 0 & 0 & 0 & 0 & 0 & 0 & 0 & 0 & $\%$ \\
\hline TOTAL & 0 & 0 & 0 & 0 & 0 & 0 & 0 & 0 & $\%$ \\
\hline \multicolumn{10}{|l|}{ Pharmacy } \\
\hline FLORIDA RESIDENT & 125 & 111 & 125 & 202 & 292 & 337 & 360 & 360 & $26.5 \%$ \\
\hline NON-RESIDENT & 0 & 8 & 0 & 23 & 33 & 38 & 40 & 40 & $38.0 \%$ \\
\hline TOTAL & 125 & 119 & 125 & 225 & 325 & 375 & 400 & 400 & $27.4 \%$ \\
\hline
\end{tabular}




\section{ACADEMIC PROGRAM COORDINATION}

New Programs To Be Considered by University in 2013-14 for Implementation

\begin{tabular}{|c|c|c|c|c|c|}
\hline $\begin{array}{r}\text { PROGRAM TITLES } \\
\end{array}$ & $\begin{array}{cc}\text { CIP } & \text { AREA OF } \\
\text { CODE } & \text { STRATEGIC } \\
\text { 6-digit } & \text { EMPHASIS } \\
\end{array}$ & $\begin{array}{c}\text { OTHER } \\
\text { UNIVERSITIES } \\
\text { WITH SAME } \\
\text { PROGRAM } \\
\end{array}$ & $\begin{array}{c}\text { OFFERED } \\
\text { VIA } \\
\text { DISTANCE } \\
\text { LEARNING } \\
\text { IN SYSTEM } \\
\end{array}$ & $\begin{array}{c}\text { PROJECTED } \\
\text { ENROLLMENT } \\
\text { in 5th year }\end{array}$ & $\begin{array}{l}\text { PROPOSED } \\
\text { DATE OF } \\
\text { T SUBMISSION } \\
\text { TO UBOT } \\
\end{array}$ \\
\hline \multicolumn{6}{|l|}{ BACHELOR'S PROGRAMS } \\
\hline BA Film and New Media Studies & 50.0602 & $\begin{array}{l}\text { FSU, UF, } \\
\text { UNF, UWF, } \\
\text { UCF, FIU, } \\
\text { FAU }\end{array}$ & & 117 & August 2013 \\
\hline BA in Biology & 26.0101 STEM & FAU/FSU & $\mathrm{N}$ & 50 & May 2014 \\
\hline BA in Org Leadership \& Super. & 52.0213 & None & $\mathrm{N}$ & 485 & May 2014 \\
\hline \multicolumn{6}{|c|}{ MASTER'S, SPECIALIST AND OTHER ADVANCED MASTER'S PROGRAMS } \\
\hline MS in Metabolic \& Nutritional Medicine & 26.9999 STEM & None & $N / Y$ & 37.5 & August 2013 \\
\hline MS in Cyber Security & 43.0303 STEM & None & Partial & 100 & October 2013 \\
\hline MS in Computer Science & 11.0701 STEM & None & $\mathrm{N}$ & 35 & May 2014 \\
\hline MS in Strategy and Information Analysis & 11.0401 STEM & None & $\mathrm{N}$ & 50 & May 2014 \\
\hline MS in Athletic Training & 51.0913 & FIU & $\mathrm{N}$ & 30 & May 2014 \\
\hline MS in Child \& Adol Beh Health & 44.0000 & None & $\mathrm{N}$ & 30 & May 2014 \\
\hline MA in Museum Studies & 30.1401 & UF & $\mathrm{N}$ & 35 & May 2014 \\
\hline \multicolumn{6}{|l|}{ DOCTORAL PROGRAMS } \\
\hline PhD Rehabilitation Sciences & 51.2314 & UF & Partial & 20 & August 2013 \\
\hline
\end{tabular}

New Programs To Be Considered by University in 2014-16 for Implementation OFFERED

VIA OTHER DISTANCE PROPOSED CIP AREA OF UNIVERSITIES LEARNING PROJECTED DATE OF PROGRAM TITLES CODE STRATEGIC WITH SAME IN ENROLLMENT SUBMISSION 6-digit EMPHASIS PROGRAM SYSTEM in 5th year TO UBOT

\section{BACHELOR'S PROGRAMS}

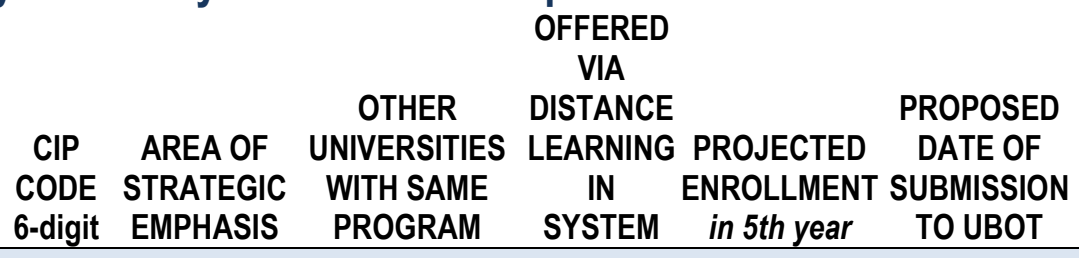

\section{MASTER'S, SPECIALIST AND OTHER ADVANCED MASTER'S PROGRAMS}

\begin{tabular}{lllllll}
\hline MA Diplomacy and Strategic Studies & 30.2011 & & FIU & Partial & 35 & August 2015 \\
\hline DOCTORAL PROGRAMS & & & & & & \\
\hline Translational Neurosciences & 26.0608 & STEM & None & Partial & 20 & August 2015 \\
\hline
\end{tabular}




\section{KEY PERFORMANCE INDICATOR DEFINITIONS}

\section{Goals Common to All Universities \\ Academic Quality \\ National Ranking for University and Program(s)}

Avg. SAT Score (for 3 subtests)

\section{Avg. HS GPA}

\section{Professional/Licensure Exam \\ First-time Pass Rates}

Exams Above National/State Benchmark

Exams Below National/State Benchmark

\section{Percent of Undergraduate Seniors Participating in a Research Course}

\section{Operational Efficiency}

\section{Freshman Retention Rate}

\section{FTIC Graduation Rates}

In 4 years (or less)

In 6 years (or less)

\section{AA Transfer Graduation Rates \\ In 2 years (or less) \\ In 4 years (or less)}

\section{Percent of Bachelor's Degrees Without Excess Hours}

\section{Average Time to Degree (for FTIC)}

Describe plans for increasing national preeminence of University and select programs.

The average SAT score for all three subtests (reading, mathematics and writing) for Admitted \& Registered FTIC (B,E) students (Fall only).

The average HS GPA for Admitted \& Registered FTIC and early admit $(B, E)$ students. Max score is 5.0 .

The number of exams with first-time pass rates above and below the national or state average, as reported in the 2011-12 Accountability report, including: Nursing, Law, Medicine (3 subtests), Veterinary, Pharmacy, Dental (2 subtests), Physical Therapy, and Occupational Therapy.

This metric represents the percentage of seniors who enrolled in a Research course during their last year. Board staff will work with University officials during the summer of 2013 to determine a systemwide definition of 'a research course'.

The percentage of a full-time, first-time-in-college (FTIC) undergraduate cohort (entering in fall term or summer continuing to fall) that is still enrolled or has graduated from the same institution in the following fall term as reported in the 2011-12 Accountability report (table 4B) - see link.

As reported in the 2011-12 Accountability report (table 4D), Firsttime-in-college (FTIC) cohort is defined as undergraduates entering in fall term (or summer continuing to fall) with fewer than 12 hours earned since high school graduation. The rate is the percentage of the initial cohort that has either graduated from or is still enrolled in the same institution by the fourth or sixth academic year. Both fulltime and part-time students are used in the calculation. The initial cohort is revised to remove students, who have allowable exclusions as defined by IPEDS, from the cohort.

As reported in the 2011-12 Accountability report (table 4E), AA Transfer cohort is defined as undergraduates entering in the fall term (or summer continuing to fall) and having earned an AA degree from an institution in the Florida College System. The rate is the percentage of the initial cohort that has either graduated from or is still enrolled in the same institution by the second or fourth academic year. Both full-time and part-time students are used in the calculation. The initial cohort is revised to remove students, who have allowable exclusions as defined by IPEDS, from the cohort. As reported in the 2011-12 Accountability report (table 4J), the percentage of baccalaureate degrees awarded within $110 \%$ of the hours required for a degree. This metric computes total academic credit (minus exemptions per 1009.286, F.S.) as a percentage of catalog hours required for the students major.

This metric is the number of years between the start date (using the student's entry date) and the end date (using the last month in the term degree was granted) for a graduating class of first-time, singlemajor baccalaureates in 120 credit hour programs within a (Summer, Fall, Spring) year. The student type is based on student type at time of entry. 
Return on Investment

Bachelor's Degrees Awarded

Percent of Bachelor's Degrees in STEM

Graduate Degrees Awarded

Percent of Graduate Degrees in STEM

Percent of Baccalaureate Graduates Employed in Florida

Percent of Baccalaureate Graduates Continuing their Education (in FL)

Annual Gifts Received (\$M)

Endowment (\$M)

Goals Specific to Research Universities

Academic Quality

Faculty Awards

National Academy Members

Number of Post-Doctoral appointees
This is a count of baccalaureate degrees awarded as reported in the 2011-12 Accountability Report (table 4G) - see link.

The percentage of baccalaureate degrees that are classified as STEM by the Board of Governors in the SUS program inventory as reported in the 2011-12 Accountability Report (table 4H) - see link. This is a count of graduate degrees awarded as reported in the 2011-12 Accountability Report (table 5B) - see link.

The percentage of baccalaureate degrees that are classified as STEM by the Board of Governors in the SUS program inventory as reported in the 2011-12 Accountability Report (table 5C) - see link. This is the percentage of baccalaureate graduates with valid social security numbers that are employed in Florida during the Oct-Dec fiscal quarter based on FETPIP data - see link.

This is the percentage of baccalaureate graduates with valid social security numbers that are continuing their education in Florida during the Oct-Dec fiscal quarter based on FETPIP data - see link. As reported in the Council for Aid to Education's Voluntary Support of Education (VSE) survey in the section entitled "Gift Income Summary," this is the sum of the present value of all gifts (including outright and deferred gifts) received for any purpose and from all sources during the fiscal year, excluding pledges and bequests. (There's a deferred gift calculator at www.cae.org/vse.) The present value of non-cash gifts is defined as the tax deduction to the donor as allowed by the IRS.

Endowment value at the end of the fiscal year, as reported in the annual NACUBO Endowment Study (changed to the NACUBOCommon Fund Study of Endowments in 2009).

Awards include: American Council of Learned Societies (ACLS)

Fellows, Beckman Young Investigators, Burroughs Wellcome Fund

Career Awards, Cottrell Scholars, Fulbright American Scholars, Getty

Scholars in Residence, Guggenheim Fellows, Howard Hughes

Medical Institute Investigators, Lasker Medical Research Awards, MacArthur Foundation Fellows, Andrew W. Mellon Foundation Distinguished Achievement Awards, National Endowment for the Humanities (NEH) Fellows, National Humanities Center Fellows, National Institutes of Health (NIH) MERIT, National Medal of Science and National Medal of Technology, NSF CAREER awards (excluding those who are also PECASE winners), Newberry Library Long-term Fellows, Pew Scholars in Biomedicine, Presidential Early Career Awards for Scientists and Engineers (PECASE), Robert Wood Johnson Policy Fellows, Searle Scholars, Sloan Research Fellows, Woodrow Wilson Fellows. As reported by the Top American Research Universities - see link.

The number of National Academy members included in the National Academy of Sciences, National Academy of Engineering, and the Institute of Medicine. As reported by the Top American Research Universities - see link. As submitted to the National Science Foundation Survey of Graduate Students and Postdoctorates in Science \& Engineering (also known as the GSS) - see link. 


\section{Number of Science \& Engineering Disciplines nationally ranked in Top 100 for research expenditures}

\section{Return on Investment}

Total Research Expenditures (\$M)

Science \& Engineering Research Expenditures in non-medical/health sciences

\section{Percent of R\&D Expenditures funded from External Sources}

Patents Issued

Licenses/Options Executed

Licensing Income Received (\$M)

Number of Start-up Companies

National rank is higher than predicted by Financial Resources Ranking based on US News \& World Report

\section{Research Doctoral Degrees Awarded}

Professional Doctoral Degrees Awarded
The number of Science \& Engineering disciplines the university ranks in the top 100 (for public and private universities) based on the National Science Foundation's annual survey for R\&D expenditures, which identifies 8 broad disciplines within Science \& Engineering (Computer Science, Engineering, Environmental Science, Life Science, Mathematical Sciences, Physical Sciences, Psychology, and Social Sciences). Historically NSF provided these rankings (see tables 45-61 at link), but now data must be queried via WebCASPAR - see link.

Total expenditures for all research activities (including non-science and engineering activities) as reported on the NSF annual survey and the 2011-12 Accountability Report - see link. This metric reports the Science \& Engineering total R\&D expenditures minus the research expenditures for medical sciences as reported by the National Science Foundation. Historically NSF provided these data (see link, table 36 minus table 52), but now data must be queried via WebCASPAR - see link.

The percentage of total R\&D expenditures that come from Federal, Private Industry and Other sources (does not include State or Institutional funds) as reported in the 2011-12 Accountability Report (table 6A) - see link.

The number of patents issued in the fiscal year as reported in the 2011-12 Accountability Report (table 6A) - see link.

Licenses/options executed in the fiscal year for all technologies as reported in the 2011-12 Accountability Report (table 6A) - see link. License issue fees, payments under options, annual minimums, running royalties, termination payments, amount of equity received when cashed-in, and software and biological material end-user license fees of $\$ 1,000$ or more, but not research funding, patent expense reimbursement, valuation of equity not cashed-in, software and biological material end-user license fees of less than $\$ 1,000$, or trademark licensing royalties from university insignia. Data as reported in the 2011-12 Accountability Report (table 6A) - see link. The number of start-up companies that were dependent upon the licensing of University technology for initiation as reported in the 2011-12 Accountability Report (table 6A) - see link.

This metric compares the overall national university ranking to the financial resources rank as reported by the US News and World report.

The number of research doctoral degrees awarded annually as reported in the 2011-12 Accountability Report (table 5B) - see link

The number of professional doctoral degrees awarded annually as reported in the 2011-12 Accountability Report (table 5B) - see link 